\title{
Immunocastration in donkeys: clinical and physiological aspects
} \author{
Valdemiro Amaro da Silva Júnior ${ }^{3}$, Hélio Cordeiro Manso Filho ${ }^{4}$ and Marcos Antonio Lemos Oliveira ${ }^{2}$ \\ ${ }^{1}$ Laboratório de Bovinos de Corte e de Leite, Unidade Especializada em Ciências Agrarias (UFRN), Natal-RN, Brasil. \\ 2 Laboratório de Biotécnicas Reprodutivas, Departamento de Medicina Veterinária (UFRPE), Recife-PE, Brasil. \\ ${ }^{3}$ Laboratório de Patologia Veterinária, Departamento de Medicina Veterinária, (UFRPE), Recife-PE, Brasil. \\ ${ }^{4}$ Departamento de Zootecnia, Universidade Federal Rural de Pernambuco (UFRPE), Recife-PE, Brasil.
}

Jorge Motta Rocha', José Carlos Ferreira-Silva², Humberto Fernandes Veloso Neto', Marcelo Tigre Moura', Heder Nunes Ferreira ${ }^{2}$

\begin{abstract}
Summary: The work was aimed to evaluate testicular alterations induced by administration of immunocastration vaccine in Donkeys. A total of 12 adult Donkeys from the Northeast breed of Brazil were randomly distributed into control group (CG; $n=04)$ and immunocastration group (IG; $n=08$ ). Donkeys from IG received two doses of Bopriva ${ }^{\circledR}$ administered in an 30-day interval (Days 0 and 30$)$. Blood samples were collected for testosterone dosage in this 30-day interval, when donkeys were weighted and measured for testicular biometry (testicular volume and tone). At the end of the experiment (Day 120), all donkeys were subjected to surgical castration in order to obtain testicular samples for histopathological analysis and from epididymis for evaluation of sperm cells. There was no difference in live weight $(P>0.05)$ within $C G$ and IG groups during the experiment, however testosterone concentrations in IG donkeys were significantly $(P<0.05)$ lower after 30 and 60 days after the first vaccine, remaining in such levels until the end of the experiment. The CG did not show variations in testosterone levels during the experiment. No evidence of functional sperm cells was found in testis of IG donkeys, despite normal gametogenesis in CG. Testis from IG donkeys showed alterations in consistency and volume, suggesting a degenerative process, further confirmed by typical histopathological alterations of such pathology. Donkeys from the CG did not display these alterations. In IG donkeys, the ductal lumen of the epididymis ductal was dilated, filled with proteinaceous and eosinophilous content alongside with acidofilous germ cells. Furthermore, azoospermia was found in $75 \%$ of IG donkeys, while remaining animals showed extremely low sperm concentration and no visible motility. Finally, immunocastration is an effective approach for male donkey castration due to its low cost and ease execution with no interference on animal welfare principles.
\end{abstract}

Keywords: immunocastration, equidae, andrology, donkey, animal welfare

Citation: Rocha J. M., Ferreira-Silva J. C., Veloso Neto H. F., Moura M. T., Ferreira H. N., Silva Júnior V. A., Manso Filho H. C., Oliveira M. A. L. (2018) Immunocastration in Donkeys: clinical and physiological aspects. Pferdeheilkunde 34, 12-16; DOI $10.21836 /$ PEM20170102

Correspondence: José Carlos Ferreira-Silva, Laboratório de Biotécnicas Reprodutivas, Departamento de Medicina Veterinária (UFRPE), Rua Dom Manoel de Medeiros, SN Dois Irmãos, CEP 52171-900 Recife-PE, Brasil; ferreirasilva.jc@gmail.com carlos.ztec@gm

\section{Introduction}

Castration is defined as processes that deprive testis function. The castration of males not destined for breeding purposes allows rationalizing and easing the management practices of livestock species (Thompson 2000, Zamaratskaia and Rasmussen 2015). Furthermore, castration further improves carcass quality (i.e. reduced taint, increased marbling, and greater meat yield) and animal welfare of swine, goats, and sheep (Dunshea et al. 2001, Zanella et al. 2009, Moraes et al. 2010, Trujillo et al. 2011, Abbá et al. 2012, Lanferdini et al. 2012, Zamaratskaia and Rasmussen 2015). Male castration also aids efforts to control population of domestic dogs, cats, and donkeys (Almeida and Silva 2010, Theubet et al. 2010, Abu-Ahmed 2015, Silva et al. 2016).

Castration can be performed by surgical removal (orchiectomy), vaccination against $\mathrm{GnRH}$, or chemical means (Thompson 2000, Abou-Ahmed et al. 2012, Miller et al. 2013, Cavalieri 2017). Despite the availability of such approaches for male castration, immunization against gonodatropin-releasing hormone $(\mathrm{GnRH})$ is under investigation as an attractive approach to suppress animal reproductive capacity (Zanella et al. 2009) without detrimental effects on animal welfare in several species (Thompson 2000, Miller et al. 2013).
The GnRH is a decapeptide responsible for biosynthesis and release of follicle stimulating hormone (FSH) and luteinizing hormone $(\mathrm{LH})$, both required for proper reproduction (McDonnell et al. 1998). Currently, research on anti-GnRH vaccines is being conducted in domestic animals and wildlife (Martinuzzi et al. 2011 , Naz and Saver 2016). Active immunization against $\mathrm{GnRH}$ induces an immunological barrier between hypothalamus and adenohypophysis that neutralizes GnRH function (Zanella et al. 2009, Morais et al. 2010), that ultimately leads to gonadal inactivity.

Since, to our knowledge, the immunocastration approach has not been described in donkeys, despite the importance of such species for animal production (Almeida and Silva 2010). Thus, the work was aimed to test a low-cost practical, and efficient protocol for immunocastration of male adult donkeys, without detrimental effects on animal welfare.

\section{Material and Methods}

Animals and immunocastration

The experiment was performed from June to October of 2015, in São José de Mipibú, Rio Grande do Norte state, 
Brazil, that displays latitude $6^{\circ} 4^{\prime} 22^{\prime \prime}$ south, longitude of $35^{\circ} 14^{\prime} 6^{\prime \prime}$ west and altitude of 49 meters. A total of 12 male donkeys from the Northeast breed were selected, with age from 5 to 7 years (Mean and Standard Deviation), weight varying from 108 to $120 \mathrm{~kg}$, after clinical andrological exam as recommendations by Canisso et al. (2009). Animals were vaccinated against rabies, encephalomyelitis, influenza, and tetanus. Animals were kept under pasture conditions throughout the experiment.

Animals were randomly allocated to control group (CG) and immunocastrated group (IG). On IG ( $n=08)$, animals were treated with $1 \mathrm{~mL}$ Bopriva ${ }^{\circledR}$ (Pfizer) vaccine by subcutaneous injection on the neck and received a second dose 30 days after the first shot. For CG $(n=04)$, animals received on same dates and time, an $1 \mathrm{~mL}$ of saline solution as described above.

\section{Testosterone analysis}

Determination of testosterone serum concentration was performed in two replicates from 5 blood samples one day before vaccine shot (D0) and, furthermore, in 30 day intervals (D30, D60, D90, and D120). Samples were collected by jugular vein puncture using $5 \mathrm{~mL}$ vacutainer ${ }^{\circledR}$ tubes. Immediately after collection, blood samples were kept to rest for 60 minutes to isolate serum, which an $2 \mathrm{~mL}$ aliquot was deposited in an eppendorf $₫$ tube and stored at $-20^{\circ} \mathrm{C}$. After completion of blood sampling, material was sent to the laboratory for analysis. Testosterone concentrations were determined by a chemiluminescent assay.

\section{Testicular volume measurement}

Testicular volume was determined by the equation $Y=(33.57 \times A T)-(56.57)$ mentioned by Elwishy (1974), where AT corresponds to testicular height. Testicular volume was obtained from five measurements at the time of blood sample collection (D0, D30, D60, D90 and D120), using a pachymeter, as described by Gebers (1995).

\section{Castration surgery}

After completion of the experiment, all animals were subjected to surgical castration. After food and water fasting for 12 hours, animals were sedated with 10\% xylazine with an $1 \mathrm{mg}$ $\mathrm{kg}^{-1}$ dose and further anaesthetized with $0.05 \mathrm{mg} \mathrm{kg}^{-1}$ diazepam and $2.2 \mathrm{mg} \mathrm{kg}^{-1}$ ketamine chloridrate, adapted from Molinaro Coelho (2014). After antisepsis procedures on the scrotum, the castration surgery was performed as the technique described by Turner and Mcillwraith (2002). During the postoperative phase, animals were treated with $20.000 \mathrm{IU} \mathrm{kg}{ }^{-1}$ benzathine penicillin by via intra-muscular (IM) shot for five consecutive days and a single $5.000 \mathrm{IU}$ anti-tetanus serum dose by IM shot.

Semen from the epididymis was retrieved by the flotation technique with Botu Semen ${ }^{\circledR}$ diluent (Botupharma) after removal of testis. Semen was evaluated by optical microscopy for total motility (MT/\%) and vigor $\left(1^{-5}\right)$.

\section{Semen analysis}

In order to quantify spermatogenesis and detect putative histological alterations induced by immunocastration, testis and epididymis were subjected to longitudinal sections for removal of fragments of medial portions and further fixed by immersion in glutaraldehyde solution. Material was stored for more then seven days, washed in $70 \%$ ethanol, subject to ultra-thin cuts $(4-5 \mu \mathrm{m})$, processed and embedded in paraffin. Slides with histology samples were stained with hematoxylin and eosin. Moreover, samples were analyzed by optical microscopy (BX41, Olympus).

\section{Experimental design}

Experimental design was completely randomized with two groups (CG and IG) and 24 replicates, where eight replicates for the $C G$ and sixteen for IG, according to statistical model below:

$$
Y_{i j}=\mu+R i+\varepsilon(i i)
$$

where: $\mu=$ overall mean, $\mathrm{Ri}=$ relative fixed effect from treatment, $\varepsilon(i i)=$ aleatory error

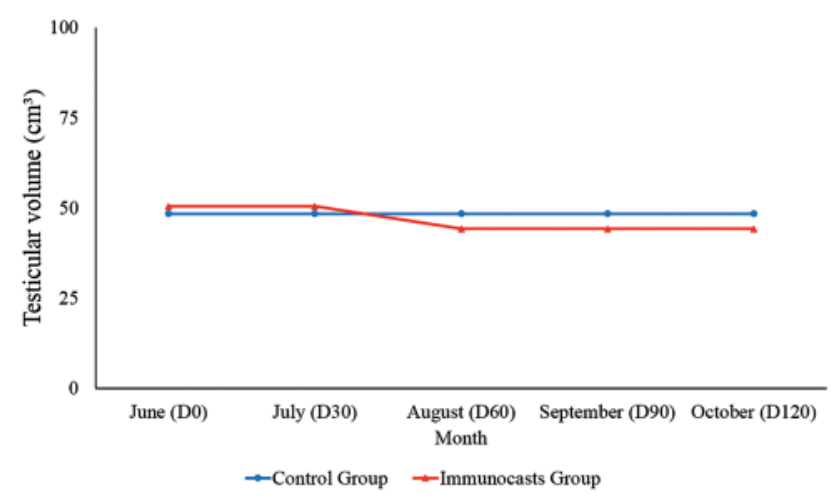

Fig. 1 Mean $( \pm s)$ serum concentration for free testosterone (ng dl-1) in control donkeys (CG) or subjected to immunocastration (IG). Mittlere ( $\pm s$ ) Serumkonzentration für freies Testosteron (ng $\mathrm{dl}^{-1}$ ) in Kontroll-Esel (CG) oder einer Immunokastration (IG) unterworfen.

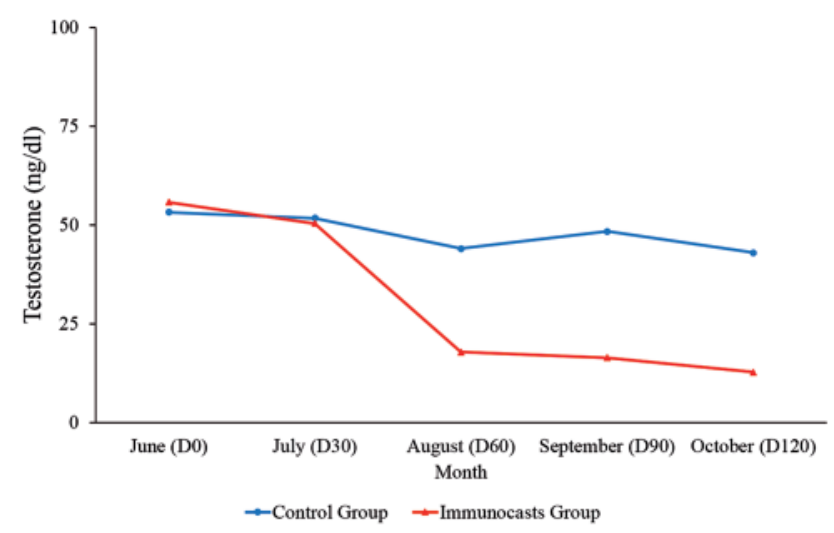

Fig. 2 Mean ( \pm s) testicular volume (TV) of control (CG) or subjected to immunocastration (IG). Mittleres ( $\pm s$ ) Hodenvolumen (TV) der Kontrolle (CG) oder einer Immunokastration (IG) unterworfen. 


\section{Statistics}

Mean, standard deviation and coefficient of variation was determined for each variable. Data was subjected to analysis of variance (ANOVA) and $F$ test with significance level of $5 \%$. Analysis were performed using a statistical software package SAS 9.3 (2012).

\section{Results}

The vaccine did not induce any local inflammatory response or adverse reaction. Moreover, animals did not display any difference for weight gain or loss, irrespectively of experimental group. Figure 1 displays mean values for free testosterone, which diminished on both groups throughout the experiment. However, the reduction in testosterone concentration was significantly higher $(P>0.05)$ on IG during August, September, and October. Figure 2 shows testicular biometry, which describes that testicular volume during the onset of the experiment was $48.44 \pm 8.40 \mathrm{~cm}^{3}$ on CG and $50.44 \pm 8.69 \mathrm{~cm}^{3}$ on IG. Testicular volume on both CG and IG did not fluctuate during the experiment, while from D60 onwards was observed reduction on testicular tonus.

Semen evaluation for CG allowed the observation that motility varied from 80 to $95 \%$ and vigor from 3.5 to 5.0. Moreover, the same analysis on IG showed that $75 \%$ (06/08) donkeys displayed azoospermia, while the two other displayed vary low sperm counts, with low motility and vigor.

Testicular histopathology on IG demonstrated severe atrophy of germinative epithelium, characterized by seminiferous epithelium desquamation and Sertoli cell vacuolization, leading to reduction in seminiferous tubule diameter, reduction in Leydig cell count and pronounced intertubular fibrosis. In con-
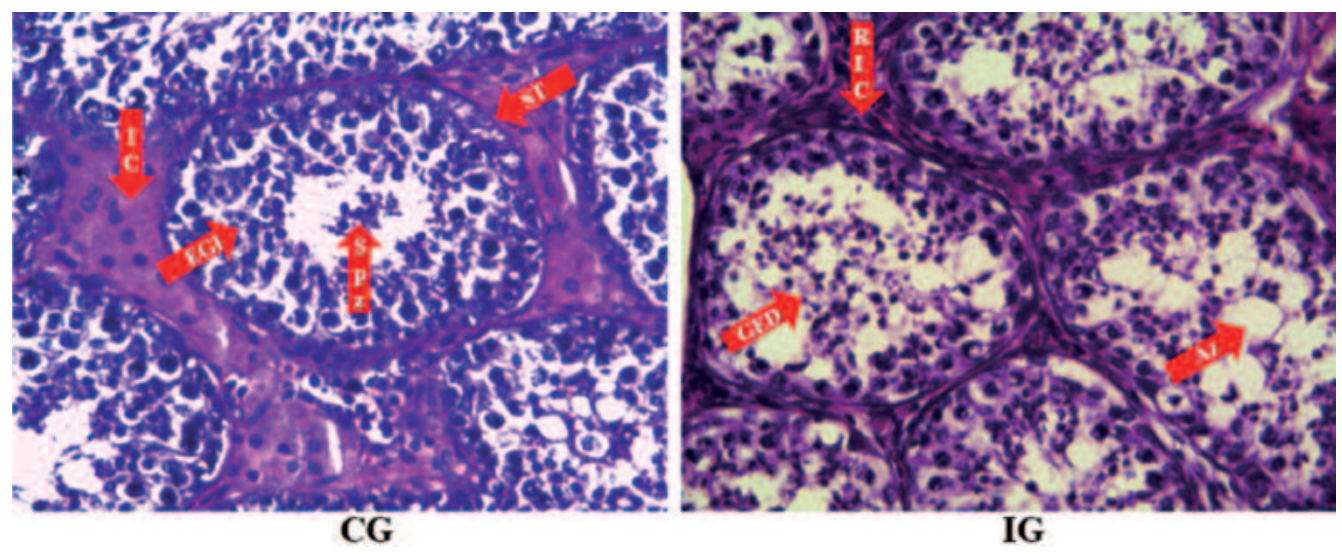

Fig. 3 Testicular histopathlogy from donkeys subjected to (IG) or not (CG) to immunocastration, stained with com hematoxylin and eosin with $100 \times$ magnifications. It shows on CG normal morphology and distribution of seminiferous tubules (ST), presence of interstitial cells (IC), intact germinative epithelium, and presence of spermatozoa (Spz) on tubule lumen. It can be observed on IG, reduced numbers of interstitial cells (RIC), germinative epithelium desquamation (GED), and azoospermy

(Az). Hodenhistopathologie von Eseln, die (IG) oder nicht (CG) zur Immunokastration unterzogen wurden, mit Com-Hämatoxylin und Eosin mit $100 \times$ Vergrößerung gefärbt. Es zeigt auf CG normale Morphologie und Verteilung von Samenröhrchen (ST), Vorhandensein von interstitiellen Zellen (IC), intaktes Keimepithel und Vorhandensein von Spermatozoen (Spz) auf Tubuluslumen. Es kann bei IG beobachtet werden, reduzierte Anzahl von interstitiellen Zellen (RIC), keimende Epithel-Abschuppung (GED) und Azoospermie (Az).
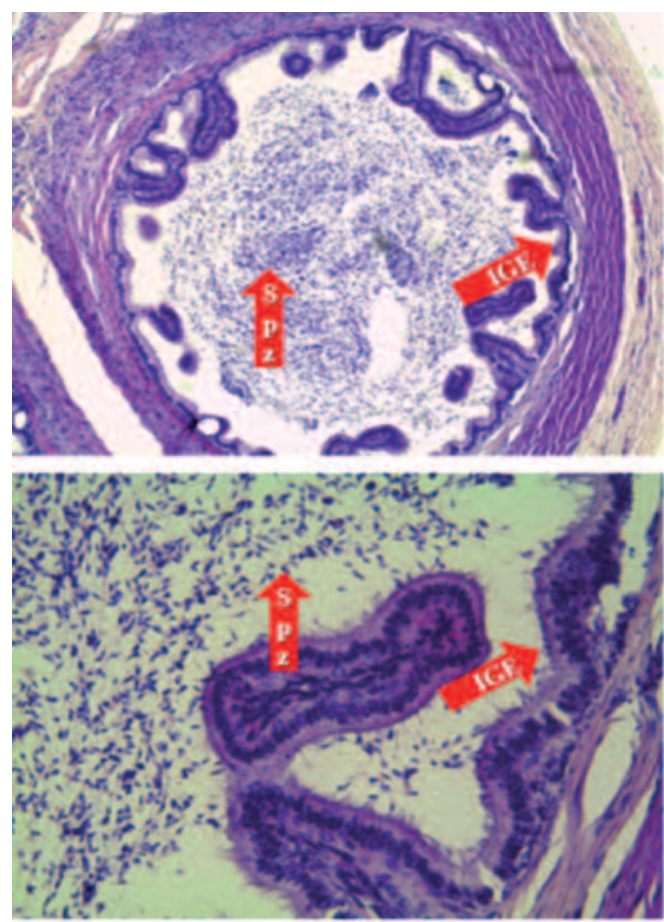

CG
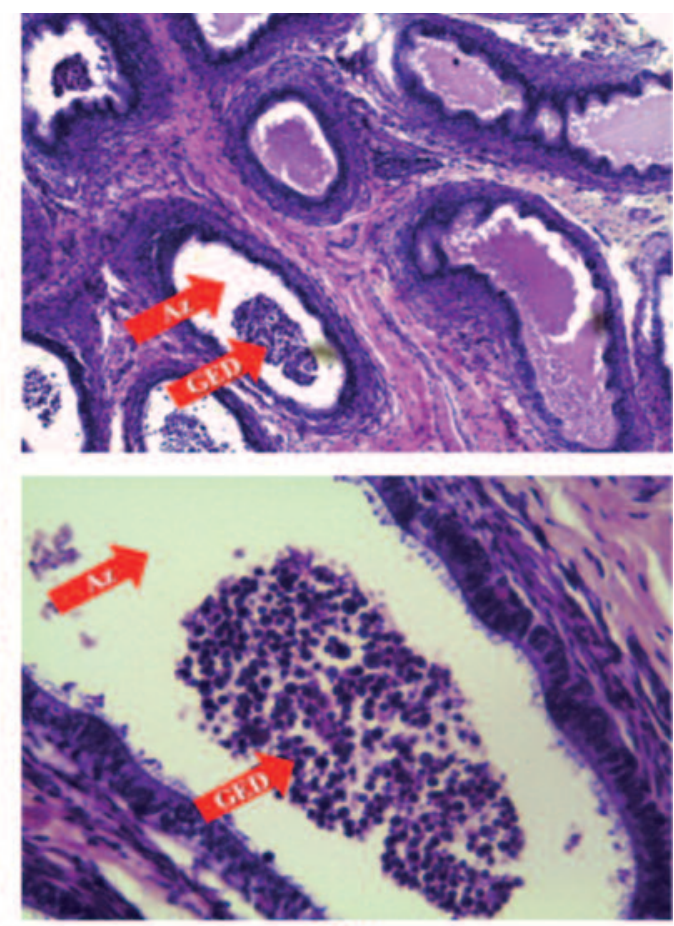

IG
Fig. 4 Epididymis histopathology from donkeys subjected (IG) or not (CG) to immunocastration, stained with com hematoxylin and eosin with $40 \times$ and $100 \times$ magnifications. It can be noted on CG the presence of spermatozoa $(\mathrm{Spz})$, intact germinative epithelium (IGE). On Gl, observed germinative epithelium desquamation (GED) and azoospermy on epidydymal duct lumen $(\mathrm{Az})$.

Epididymis-Histopathologie aus Eseln, die (IG) oder nicht (CG) einer Immunokastration unterzogen wurden, mit ComHämatoxylin und Eosin mit 40x und 100x Vergrößerung gefärbt. Es kann auf CG die Anwesenheit von Sperma (Spz), intaktes Keimepithel (IGE) vermerkt werden. Auf GI beobachtete die keimende Epithel-Abschuppung (GED) und die Azoospermie auf epidydymalem Duellumen (Az). 
trast, testicular histopathology on CG did not show these alterations (Figure 3).

Epididymis from IG animals showed epithelium with normal conformation, stroma and muscular cell layers, ductal lumen was highly dilated, with complete absence of spermatozoa in $75 \%$ animals, filled with proteinaceous and eosinophilous content alongside with germinative epithelium under desquamation and necrosis, while CG samples did not show these alterations (Figure 4).

\section{Discussion}

Castration reduces testosterone serum concentration, contributes to increase weight gain in livestock, confers more appropriate carcass traits, and minimizes male aggressive behavior in several species (Thompson 2000, Zamaratskaia et al. 2007 and 2008, Morais et al. 2010, Miller et al. 2013). Despite the efficiency of castration methods, immunocastration becomes an attractive approach due to its simplicity and since it better suites for animal welfare demands (Thompson 2000, Miller et al. 2013).

The data described here showed that free testosterone concentrations on IG reached the same levels at 30 days after the second vaccine dose that are found on surgically castrated animals. These low testosterone concentrations remained static throughout the experiment. Immunocastration studies demonstrated fast increase in anti-GnRH antibody formation after second vaccine administration, while sustaining low testosterone for several weeks, irrespectively of the species studied (Thompson 2000, Theubet et al. 2010, Zamaratskaia and Rasmussen 2015).

Mean testicular volume at experiment onset was lower then reported by Gastal et al. (1996) for the northeast breed of donkeys, even before animals were subjected to immunocastration. This finding is in agreement to genetic influence found in this breed for the trait, but possibly due to other factors such as nutrition, body development, and period of the year.

Since immunocastration inhibits $\mathrm{GnRH}$ activity toward adenohyphophisis with downstream reduction in gonadotropin synthesis and release (Dunshea et al. 2001, Zanella et al. 2009, Trujillo et al. 2011), it can be accounted for the testicular degeneration. Despite diminished testicular volume and tonus are andrological are hallmarks of testicular degeneration in livestock (Thompson 2000, Miller et al. 2013), as described in the study, these reductions were not significant, possibly due to age of the animals, period of evaluation, or species-specific factors. Thus, testis volume variation cannot aid to diagnose this pathology. Testicular degeneration was determined by histopathology exam, which showed epithelium desquamation and reduction in seminiferous tubule lumen. Moreover, Sertoli cell disfunction was also observed, also leading to non-functional spermatogenesis. These aspects were previously identified in swine (Dunshea et al. 2001, Zeng et al. 2002, Zamaratskaia et al. 2007) and bovine (Zanella et al. 2009, Theubet et al. 2010) subjected to immunocastration. Immunocastration is a viable alternative method to conventional contraceptive methods in donkeys due to its ease execution, low-cost and accordance to animal welfare demands.

\section{Conflict of interest}

None of the authors of this paper have financial or personal relationships with other people or organizations that could inappropriately influence or bias the content of the paper.

\section{Animal welfare statement}

The work was conducted in accordance to Ethic guidelines for animal use in research at Universidade Federal Rural de Pernambuco (CEUA-UFRPE license 098/2015).

\section{References}

Abbá M. G., Feliciano M. A. R., Vicente W. R. R. (2012) Características da carcaça e qualidade da carne de bezerros submetidos à orquiectomia por método de castração russa e com burdizzo. Rev. Cient. Eletrônica Med. Vet. 18, 1-12

Abou-Ahmed H. M., El-Kammar M. H., El-Neweshy M. S., AbdelWahed R. E. (2012) Comparative Evaluation of Three In Situ Castration Techniques for Sterilizing Donkeys: Incision-Ligation (a Novel Technique), Section-Ligation-Release, and Pinhole. J. Equine Vet. Sci., 32, 711 -718

Abu-Ahmed H. M. (2015) Chemical Sterilization of Dogs using Single Bilateral Intra-testicular Injection of Calcium Chloride or Clove Oil. Alexandria J. Vet. Sci. 45, 26-32

Almeida F. Q., Silva V. P. (2010) Progresso científico em equideocultura na la década do século XXI. Rev. Bras. Zootec. 39, 119-129

Canisso I. F., Carvalho G. R., Silva E. C., Rodrigues A. L., Ker P. G., Guimarães J. D. (2009) Alguns aspectos biométricos do aparelho genital externo de jumentos doadores de sêmen da raça Pêga. Ciênc. Rural 39, 2556-2562

Cavalieri J. (2017) Chemical sterilisation of animals: A review of the use of zinc- and $\mathrm{CaCl} 2$ based solutions in male and female animals and factors likely to improve responses to treatment. Anim Reprod Sci. 181:1-8

Dunshea F. R., Colantoni C., Howard K., McCauley I., Jackson P., Long K. A., Hennessy D. P. (2001) Vaccination of boars with a $\mathrm{GnRH}$ vaccine (Improvac) eliminates boar taint and increases growth performance. J. Anim. Sci. 79, 2524-2535

Elwishy A. B. (1975) Morphology of epididymal spermatozoa in the ass (Equus asinus) and stallion (Equus caballus). Z. Tierzuecht. Zuechtungsbiol. 92, 67-72

Gastal M. O., Henry M., Beker A. R., Gastal E. L. (1996) Sexual behavior of donkey jacks: influence of ejaculatory frequency and season. Theriogenology 46, 593-603

Gebaver M. R., Pickett B. W., Voss J. L., Swierstra E. E. (1974) Reproductive physiology of the stallion: daily sperm output and testicular measurements. J. Am. Vet. Med. Assoc. 165, 711-713

Lanferdini E., Lovatto P. A., Melchior R., Klein C. C., Broch J., Garcia G. G. (2012) Carcass characteristics and meat of surgically castrated and immunocastrated pigs fed different nutritional levels. Ciênc. Rural 42, 2071-2077

Martinuzzi P. A., Viana A. N., Kussler A., Cereser N. D. (2011) Imunocastração em suínos. Seminário Interinstitucional de Ensino, Pesquisa e Extensão, v. 16, 2011.

McDonnell S. M. (1998) Reproductive behavior of donkeys (Equus asinus). Appl. Anim. Behav. Sci. 60, 277-282

Miller L. A., Fagerstone K. A., Eckery D. C. (2013) Twenty years of immunocontraceptive research: lessons learned. J. Zoo Wildl. Med. 44, S84-S96

Molinaro Coelho C. M., Duque Moreno J. C., Goulart D. D. S., Caetrano L. B., Soares L. K., Coutinho G. H., Alves G. E. S., Silva L. A. $F$ (2014) Evaluation of cardiorespiratory and biochemical effects of ketamine propofol and guaifenesin ketamine xylazine anesthesia in donkeys (Equus asinus). Vet. Anaesth. Analg. 41, 602-612

Moraes E., Kiefer C., Silva I. S. (2010) Ractopamina em dietas para suínos machos imunocastrados, castrados e fêmeas. Ciênc. Rural 40, 409-414 
Naz R. K., Saver A. E. (2016) Immunocontraception for animals: current status and future perspective. Am. J. Reprod. Immunol. 75, 426-439

Robertson I. S., Fraser H. M., Innes G. M., Jones A. S. (1982) Effect of immunological castration on sexual and production characteristics in male cattle. Vet. Rec. 111, 529-531

Silva S. B. D., Farias J., Barros R., Andrade G. (2016) Castração em pequenos animais. Revista de Iniciação Científica da Universidade Vale do Rio Verde 5.

Theubet G., Thun R., Hilbe M., Janett F. (2010) Wirkung einer Impfung gegen $\mathrm{GnRH}$ (Bopriva ${ }^{\circledR}$ ) beim männlichen pubertären Kalb. Schweiz. Arch. für Tierheilkd. 152, 459-469

Thompson D. L. (2000) Immunization against GnRH in male species (comparative aspects). Anim Reprod Sci. 60-61, 459-469

Trujillo J. H. A., Pineda J. F. E., Gonzalez P. A. G. (2011) Immunocastration: a humane and effective alternative to surgical castration of adult boars. Rev. Colom. Ciênc. Pecuá. 24, $254-$ 262

Turner A. S., Mcllwraith C. W. (2002) Técnicas cirúrgicas em animais de grande porte. São Paulo: Roca, 341 p.
Zamaratskaia G., Gilmore W. J., Lundström K., Squires, E. J. (2007) Effect of testicular steroids on catalytic activities of cytochrome P450 enzymes in porcine liver microsomes. Food Chem. Toxicol. 45, 676-681

Zamaratskaia G. L., Rydhmer H. K., Andersson H. K., Chen G., Lowagie S., Andersson K., Lundström K. (2008) Long-term effect of vaccination against gonadotropin-releasing hormone, using Improvac ${ }^{\mathrm{TM}}$, on hormonal profile and behaviour of male pigs. Anim. Reprod. Sci. 108, 37-48

Zamaratskaia G. Rasmussen M. K. (2015) Immunocastration of male pigs - situation today. Procedia Food Science 5, 324-327

Zanella R., Zanella E. R., Reeves J. J., Hernandez J., Motta A. C., Avila D. (2009). Características testiculares de touros imunizados com vacina anti-hormônio liberador do hormônio luteinizante. Pesq. Agropec. Bras. 44, 1359-1363

Zeng X. Y., Turkstra J. A., Meloen R. H., Liu X. Y., Chen F. Q., Schaaper W. M., Oonk H. B., Guo D. Z., Van De Wiel D. F. (2002) Effects of active immunization against $\mathrm{GnRH}$ on serum $\mathrm{LH}$, inhibin A, sexual development and growth rate in Chinese female pigs. Theriogenology 58, 1315-1326 